УДК 633.822: 577.19

\title{
БИОЛОГИЧЕСКИ АКТИВНЫЕ ВЕЩЕСТВА MENTHA SPICATA L.
}

\author{
() О.А. Гребенникова", А.Е. Палий, Ю.П. Христова \\ Никитский ботанический сад, п.г.т. Никита, Ялта, Республика Крым, 298648 \\ (Россия), e-mail: oksanagrebennikova@yandex.ru
}

В статье приведены данные о качественном и количественном составе биологически активных веществ (летучих соединений, фенольных веществ, витаминов) водно-этанольного экстракта перспективного сортообразца Mentha spicata L. селекции НБС-ННЦ. Концентрация летучих соединений в водно-этанольном экстракте мяты колосовой составила 373,8 мг/100 г. В экстракте обнаружено 46 компонентов, идентифицировано - 42. Основные и наиболее ценные летучие соединения экстракта мяты колосовой - карвон $(29,3 \%)$ и лимонен $(9,7 \%)$. Содержание фенольных веществ в водно-этанольном экстракте мяты колосовой составило 2260,0 мг/100 г. В экстракте обнаружено 17 компонентов. Среди фенольных веществ экстракта мяты колосовой доминирует розмариновая кислота $(57,8 \%)$. Сделан вывод о возможности использования экстракта для создания пищевой и лечебно-профилактической продукции.

Ключевые слова: Mentha spicata L., водно-этанольный экстракт, хромато-масс-спектрометрия, ВЭЖХ, летучие соединения, фенольные вещества, витамины.

\section{Введение}

Род мята (Mentha L.) относится к семейству яснотковых (Lamiaceae Lindl.) и включает, по данным разных авторов, от 18 до 30 видов [1-3]. Одним из наиболее важных видов этого рода является мята колосовая (Mentha spicata L.) - коммерческая эфиромасличная культура, культивируемая практически во всем мире [4-6]. Мята колосовая и ее эфирное масло находят широкое применение в медицинской, парфюмерной и пищевой промышленности, а также в народной медицине [1, 2, 4, 6-9]. Трава и эфирное масло мяты оказывают бактерицидное, фунгицидное, болеутоляющее, желчегонное, ветрогонное и потогонное действие $[2,3,6,10]$. В последнее время получены экспериментальные данные об антиоксидантной активности этого растения [3, 4, 11, 12]. Эфирное масло мяты колосовой входит в состав средств, помогающих при лечении астмы, артритов, бронхитов, катаров, мигреней, переутомлений, укачиваний, нервных возбуждений, нарушений пищеварения, болезней печени и мышц [1, 2, 6, 7].

Биологическая ценность сырья мяты колосовой обусловлена содержанием ряда биологически активных веществ, таких как летучие соединения, фенольные вещества и витамины.

Основными компонентами эфирного масла мяты колосовой являются монотерпеновые соединения. В пределах данного вида из разных географических зон и различных мест культивирования выделяют несколь-

Гребенникова Оксана Анатольевна - кандидат биологических наук, научный сотрудник отдела физиолого-биохимических исследований, биотехнологии и репродуктивной биологии растений, e-mail: oksanagrebennikova@ yandex.ru

Палий Анфиса Евгеньевна - кандидат биологических наук, заведующая измерительной лабораторией отдела физиолого-биохимических исследований, биотехнологии и репродуктивной биологии растений, e-mail: onlabor@yandex.ru

Христова Юлия Петровна - младший научный сотрудник лаборатории новых ароматических и лекарственных растений, e-mail: julia_christova05@rambler.ru ко хемотипов, тем не менее наиболее распространена мята колосовая карвонного хемотипа, обладающая запахом этого соединения [11, 13-5]. Так, эфирные масла мяты колосовой из США, Египта и Индии отличаются высоким содержанием карвона $(49,6-76,6 \%)$, лимонена $(9,5-22,3 \%)$ и 1,8-цинеола (до 6,8\%) [11, 14, 15]. Доминирующими компонентами эфирного масла мяты колосовой, выращиваемой в Марокко, являются карвон $(53,7-57,1 \%)$, лимонен $(27,8-31,1 \%)$ и транскарвеол (до 3,9\%) [8], в Бангладеш - карвон (73,3\%), лимонен $(7,6 \%)$ и дигидрокарвон $(3,8 \%)$ [16], в Турции - карвон $(50,3 \%)$, лимонен $(16,5 \%)$ и борнеол $(3,9 \%)$

\footnotetext{
*Автор, с которым следует вести переписку.
} 
[9], в Алжире - карвон (59,4\%), лимонен (6,1\%) и гермакрен D $(4,7 \%)$ [2], в Сербии - карвон (49,5\%), ментон $(21,9 \%)$, лимонен $(5,8 \%)$ и 1,8-цинеол $(3,0 \%)$ [17], в Португалии - карвон $(41,1 \%)$, лимонен $(20,1 \%)$ и копаен $(5,6 \%)$ [11]. Основными компонентами эфирного масла из Северной Индии являются карвон и пиперитон оксид [12]. Различные хемотипы мяты колосовой культивируются в Китае: карвонный, оксипиперитонный и пулегонный [5], Эстонии: карвонный, оксипиперитонный и терпенилацетатный [18] и Иране: оксипиперитонный, цинеольный и карвонный [19]. Основные компоненты болгарского эфирного масла: 1,8-цинеол, $n$-цимен, карвакрол и тимол [20]. Таким образом, компонентный состав эфирного масла мяты колосовой значительно отличается в зависимости от почвенно-климатических и генетических факторов.

Фенольные соединения мяты колосовой представлены фенолкарбоновыми кислотами и их производными, флавоноидами и дубильными веществами $[4,7,21,22]$. В мяте колосовой, выращенной в Пакистане и Турции, идентифицированы кофейная, розмариновая и феруловая кислоты $[21,22]$. Флавоноиды мяты колосовой - лютеолин и его гликозиды $[4,21]$.

В связи с этим актуальна интродукция и селекция мяты в условиях Крыма, а также изучение ее биологически активных веществ. В Никитском ботаническом саду - Национальном научном центре ведется работа по выведению новых сортов мяты колосовой, среди которых по ряду хозяйственно-ценных признаков был выделен данный сортообразец.

Таким образом, целью настоящей работы явилось изучение качественного и количественного состава биологически активных веществ (летучих соединений, фенольных веществ, витаминов) в водноэтанольном экстракте перспективного сортообразца мяты колосовой селекции НБС - ННЦ для обоснования целесообразности создания на его основе продукции с высокой биологической ценностью.

\section{Объекты и методы}

Объектом исследования явилось сырье перспективного сортообразца мяты колосовой (Mentha spicata L.), собранной на коллекционных участках Никитского ботанического сада в период цветения.

Содержание летучих веществ определяли в водно-этанольном экстракте, приготовленном из воздушно-сухого растительного сырья. Экстракцию проводили 50\%-м раствором этанола при соотношении сырья к растворителю $1: 10$ настаиванием в течение 10 суток при комнатной температуре.

Компонентный состав летучих веществ определяли с помощью хроматографа Agilent Technology 6890 с масс-спектрометрическим детектором 5973. Колонка HP-1 длиной 30 м; внутренний диаметр 0,25 мм. Температура термостата программировалась от 50 до $250{ }^{\circ} \mathrm{C}$ со скоростью $4{ }^{\circ} \mathrm{C} /$ мин. Температура инжектора $-250{ }^{\circ} \mathrm{C}$. Газ-носитель - гелий, скорость потока $1 \mathrm{~cm}^{3} /$ мин. Перенос от газового хроматографа к масс-спектрометрическому детектору прогревался до $230^{\circ} \mathrm{C}$. Температура источника поддерживалась на уровне $200{ }^{\circ} \mathrm{C}$. Электронная ионизация проводилась при $70 \mathrm{eV}$ в ранжировке масс $\mathrm{m} / \mathrm{z}$ от 29 до 450. Идентификация выполнялась на основе сравнения полученных масс-спектров с данными комбинированной библиотеки NIST05-WILEY2007 (около 500000 масс-спектров).

Компонентный состав фенольных веществ определяли на хроматографе фирмы Agilent Technologies (модель 1100), укомплектованном проточным вакуумным дегазатором G1379A, четырехканальным насосом градиента низкого давления G13111A, автоматическим инжектором G1313A, термостатом колонок G13116A, диодноматричным детектором G1316A. Для проведения анализа была использована хроматографическая колонка размером 2,1×150 мм, заполненная октадецилсилильным сорбентом ZORBAX-SB C-18 зернением 3,5 мкм. При анализе применяли градиентный режим хроматографирования, предусматривающий изменение в элюирующей смеси соотношения компонентов A $(0,1 \%$ ортофосфорная кислота; $0,3 \%$ тетрагидрофуран; $0,018 \%$ триэтиламин) и В (метанол). Скорость подачи подвижной фазы составила $0,25 \mathrm{~cm}^{3} /$ мин; рабочее давление элюента - 240-300 кПа; объем пробы - 2 мкл; время сканирования - 0,5 с; масштаб измерений 1,0. Идентификацию фенольных веществ проводили по времени удерживания стандартов и спектральным характеристикам (параметры снятия спектра - каждый пик 190-600 нм; длины волн 280, 313, 350, 371 нм) [23, 24].

Суммарное содержание фенольных веществ определяли фотометрическим методом с использованием реактива Фолина-Чокальтеу [25], каротиноидов - фотометрическим методом [26], аскорбиновой кислоты - йодометрически - титрованием [27].

\section{Результаты и обсуждение}

В результате проведенных исследований установлено, что концентрация летучих соединений в водно-этанольном экстракте мяты колосовой составила 373,8 мг на 100 г воздушно-сухого растительного сырья, в нем обнаружено 46 компонентов, из которых идентифицировано 42 (табл. 1). 
Таблица 1. Компонентный состав летучих соединений водно-этанольного экстракта Mentha spicata $\mathrm{L}$

\begin{tabular}{|c|c|c|c|}
\hline № & Время выхода, мин & Компонент & Массовая доля, \% \\
\hline 1 & 5,52 & $\alpha$-пинен & 0,30 \\
\hline 2 & 6,55 & сабинен & 0,10 \\
\hline 3 & 6,63 & $\beta$-пинен & 0,68 \\
\hline 4 & 7,05 & мирцен & 0,50 \\
\hline 5 & 8,12 & лимонен & 9,70 \\
\hline 6 & 8,28 & 1,8-цинеол & 0,59 \\
\hline 7 & 8,41 & цүис-оцимен & 0,09 \\
\hline 8 & 8,73 & транс-оцимен & 0,12 \\
\hline 9 & 9,05 & $\gamma$-терпинен & 0,23 \\
\hline 10 & 9,38 & транс-сабиненгидрат & 0,17 \\
\hline 11 & 10,51 & нонаналь & 0,09 \\
\hline 12 & 11,05 & ичис-nара-мент-2-ен-1-ол & 0,36 \\
\hline 13 & 11,52 & транс-пара-мент-2-ен-1-ол & 0,12 \\
\hline 14 & 11,59 & транс-лимоненоксид & 0,09 \\
\hline 15 & 11,8 & камфора & 0,15 \\
\hline 16 & 12,31 & пинокамфон & 0,20 \\
\hline 17 & 13,33 & $\alpha$-терпинеол & 0,27 \\
\hline 18 & 13,52 & циис-дигидрокарвон & 15,06 \\
\hline 19 & 13,76 & транс-дигидрокарвон & 0,30 \\
\hline 20 & 15,09 & карвон & 29,31 \\
\hline 21 & 15,38 & пиперитон & 0,11 \\
\hline 22 & 16,14 & карвоноксид & 0,15 \\
\hline 23 & 16,98 & тимол & 1,54 \\
\hline 24 & 17,07 & карвакрол & 1,24 \\
\hline 25 & 17,74 & дигидрокарвилацетат & 6,28 \\
\hline 26 & 18,01 & цис-карвилацетат & 0,33 \\
\hline 27 & 18,72 & транс-карвилацетат & 1,20 \\
\hline 28 & 19,01 & $\alpha$-копаен & 0,16 \\
\hline 29 & 19,25 & $\beta$-бурбонен & 0,83 \\
\hline 30 & 20,08 & $\beta$-кариофиллен & 0,68 \\
\hline 31 & 20,4 & транс-лимонен-диоксид & 0,81 \\
\hline 32 & 20,82 & цис-лимонен-диоксид & 0,22 \\
\hline 33 & 23,31 & кариофилленоксид & 0,43 \\
\hline 34 & 28,58 & пальмитиновая кислота & 1,76 \\
\hline 35 & 28,88 & этилпальмитолеат & 0,30 \\
\hline 36 & 28,95 & этил пальмитат & 2,89 \\
\hline 37 & 30,37 & фитол & 5,22 \\
\hline 38 & 30,6 & линолеовая кислота & 0,72 \\
\hline 39 & 30,69 & линоленовая кислота & 3,33 \\
\hline 40 & 30,9 & этил линолеат & 1,49 \\
\hline 41 & 30,98 & этил линоленат & 11,01 \\
\hline 42 & 31,23 & этилстеарат & 0,28 \\
\hline
\end{tabular}

Для водно-этанольного экстракта данного сортообразца наиболее характерны такие летучие вещества, как монотерпеновые кетоны, монотерпены и алифатические соединения, в частности, сложные эфиры. Преобладающими компонентами являются карвон $(29,3 \%)$, цис-дигидрокарвон $(15,1 \%)$, этиллиноленат $(11,0 \%)$ и лимонен $(9,7 \%)$. Кроме того, отмечено значительное содержание дигидрокарвилацетата и фитола. Учитывая высокую внутривидовую изменчивость качественного состава эфирного масла мяты колосовой, полученные нами данные для водно-этанольного экстракта вполне согласуются с данными из литературных источников, представленными для эфирного масла этого растения $[8,16]$.

Наиболее ценными летучими соединениями мяты колосовой, содержащимися в полученном экстракте, являются карвон и лимонен. Высокое содержание карвона в экстракте не только придает ему приятный, характерный для этого растения аромат, но и обеспечивает сильный противогрибковый эффект [17]. Вместе с тем этот монотерпеновый кетон обладает значительной антимикробной активностью [2, 15]. Более слабо выраженную антимикробную активность, наряду с приятным запахом, имеет и лимонен [15]. Кроме того, некоторые исследователи полагают, что антиоксидантные свойства мяты колосовой обусловлены содержанием в ней монотерпеноидов, в частности лимонена и карвона [11].

При исследовании фенольных соединений выявлено, что их концентрация в водно-этанольном экстракте данного сортообразца мяты колосовой составила 2260,0 мг на 100 г воздушно-сухого растительного сырья (табл. 2). 
Таблица 2. Компонентный состав фенольных соединений в водно-этанольном экстракте Mentha spicata $\mathrm{L}$

\begin{tabular}{c|l|l|c}
\hline$№$ п/п & Время выхода, мин & \multicolumn{1}{|c}{ Компонент } & Концентрация, мг/100 г сырья \\
\hline 1 & 18,44 & изомер хлорогеновой кислоты & 9,9 \\
2 & 19,99 & изомер хлорогеновой кислоты & 15,2 \\
3 & 24,92 & кофейная кислота & 27,3 \\
4 & 26,81 & изомер хлорогеновой кислоты & 23,0 \\
5 & 28,5 & изомер хлорогеновой кислоты & 10,3 \\
6 & 34,2 & изомер хлорогеновой кислоты & 72,7 \\
7 & 47,29 & гликозид лютеолина & 56,8 \\
8 & 47,75 & гликозид лютеолина & 128,8 \\
9 & 48,16 & лютеолин-7-гликозид & 1307,8 \\
10 & 51,48 & розмариновая кислота & 53,7 \\
11 & 53,69 & гликозид лютеолина & 50,6 \\
12 & 55,53 & гликозид лютеолина & 59,8 \\
13 & 57,35 & гликозид лютеолина & 72,3 \\
14 & 58,73 & гликозид лютеолина & 123,9 \\
15 & 62,28 & гликозид лютеолина & 108,3 \\
16 & 64,56 & гликозид лютеолина & 122,9 \\
17 & 68,07 & гликозид лютеолина & \\
\hline
\end{tabular}

В экстракте обнаружено 17 компонентов, из которых идентифицировано 3 (кофейная кислота, розмариновая кислота и лютеолин-7-гликозид), а для остальных установлена природа. Экстракт содержит кофейную кислоту, изомеры хлорогеновой кислоты, розмариновую кислоту и гликозиды лютеолина, что согласуется с результатами зарубежных исследователей [4, 21, 22].

В экстракте преобладают гидроксикоричные кислоты, содержание которых превышает $62 \%$. Доминирующим компонентом является розмариновая кислота, составляющая $57,8 \%$ от общего количества фенольных веществ. Розмариновая кислота обладает антиоксидантными, антибактериальными и противовирусными свойствами [21, 28-30]. Кроме того, розмариновая кислота оказывает положительное терапевтическое действие при лечении бронхиальной астмы, пептической язвы, воспалительных заболеваний, гепатотоксичности, атеросклероза, ишемической болезни сердца, катаракты, рака $[28,30]$.

В водно-этанольном экстракте изучаемого сортообразца мяты колосовой содержится 19,54 мг/дм ${ }^{3}$ аскорбиновой кислоты и 3,28 мг/дм ${ }^{3}$ каротиноидов.

Таким образом, водно-спиртовый экстракт данного сортообразца мяты колосовой содержит летучие соединения, доминирующими из которых являются карвон и лимонен, гидроксикоричные кислоты с преобладанием розмариновой кислоты, гликозиды лютеолина, аскорбиновую кислоту и каротиноиды и может использоваться для создания различных видов продукции с высокой биологической ценностью.

\section{Bblbodbl}

Определен качественный и количественный состав биологически активных веществ (летучих соединений, фенольных веществ, витаминов) в водно-этанольном экстракте перспективного сортообразца мяты колосовой.

Установлено, что водно-этанольный экстракт исследованного сортообразца мяты колосовой содержит высокие концентракии как летучих соединений $(373,8$ мг/100 г), так и фенольных веществ $(2260,0$ мг/100 г).

Основные и наиболее ценные летучие соединения экстракта мяты колосовой - карвон $(29,3 \%)$ и лимонен $(9,7 \%)$.

Среди фенольных соединений экстракта мяты колосовой доминирует розмариновая кислота (57,8\%).

Проведенные исследования подтверждают возможность использования водно-спиртового экстракта мяты колосовой для создания продукции с высокой биологической ценностью.

\section{Список литературь}

1. Arumugam P., Ramamurthy P., Thyagarajan Santhiya S., Ramesh A. Antioxidant activity measured in different solventfractions obtained from Mentha spicata Linn.: Ananalysis by ABTS.+ decolorization assay // Asia Pac J Clin Nutr. 2006. Vol. 15. N1. Pp. 119-124.

2. Boukhebti H., Nadjib Chaker A., Belhadj H., Sahli F., Ramdhani M., Laouer H., Harzallah D. Chemical composition and antibacterial activity of Mentha pulegium L. and Mentha spicata L. essential oils // Der Pharm. Lett. 2011. Vol. 3. N4. Pp. 267-275. 
3. Nickavar B., Alinaghi A., Kamalinejad M. Evaluation of the antioxidant properties of five Mentha species // Iran. J. of Pharm. Res. 2008. Vol. 7. N3. Pp. 203-209.

4. Fialová S., Tekel'ová D., Mrlianová M., Grančai D. The determination of phenolics compounds and antioxidant activity of Mints and Balms cultivated in Slovakia // Acta facultatis pharmaceuticae universitatis comenianae. 2008. Vol. 55. Pp. 96-102.

5. Hua C.X., Wang G.R., Lei Y. Evaluation of essential oil composition and DNA diversity of mint resources from China // Afri. J. Biotechnol. 2011. Vol. 10. Pp. 16740-16745.

6. Naidu J.R., Ismail R.B., Yeng C., Sasidharan S., Kumar P. Chemical composition and antioxidant activity of the crude methanolic extracts of Mentha spicata // Phytology. 2012. Vol. 4. N1. Pp. 13-18.

7. Al-Tawaha A., Al-Karaki G., Massadeh A. Comparative response of essential oil composition, antioxidant activity and phenolic contents spearmint (Mentha spicata L.) under protected soilless vs. open field conditions // Adv. Environ. Biol. 2013. Vol. 7. N5. Pp. 902-910.

8. Bensabah F., Lamiri A., Naja J. Effect of purified wastewater from the city of Settat (Morocco) on the quality of spearmint essential oil (Mentha spicata) // Int. J. Engin. Sci. and Technol. 2013. Vol. 3. N1. Pp. 44-48.

9. Kizil S., Naşimi N., Tolan V., Kilinç E., Yüksel U. Mineral content, essential oil components and biological activity of two mentha species (M. piperita L., M. spicata L.) // Turk. J. of Field Crops. 2010. Vol. 15. N2. Pp. 148-153.

10. Shailendra Singh C., Ruchi A. Evaluation of antibacterial activity of volatile oil from Mentha spicata L. // J. of Drug Delivery Therapeutics. 2013. Vol. 3. N4. Pp. 120-121.

11. Martins M.R., Tinoco M.T., Almeida A.S., Cruz-Morais J. Chemical composition, antioxidant and antimicrobial properties of three essential oils from Portuguese flora // Pharmacognosy. 2012. Vol. 3. N1. Pp. 39-44.

12. Raturi P., Sharma A. Antibacterial and antioxidant activity of essential oil extracted from Mentha spicata L. // Int. J. of Engin. and Mathem. Sci. 2012. Vol. 1. N1. Pp. 22-26.

13. Abd El-Wahab M.A. Evaluation of spearmint (Mentha spicata L.) productivity grown in different locations under upper Egypt conditions // Res. J. Agric. Biol. Sci. 2009. Vol. 5. N3. Pp. 250-254.

14. Padalia R.C., Verma R.S., Chauhan A., Sundaresan V., Chanotiya C.S. Essential oil composition of sixteen elite cultivars of Mentha from western Himalayan region, India // Maejo Int. J. Sci. Technol. 2013. Vol. 7. N1. Pp. 83-93.

15. Roldan L.P., Diaz G.J., Duringer J.M. Composition and antibacterial activity of essential oils obtained from plants of the Lamiaceae family against pathogenic and beneficial bacteria // Rev Colomb Cienc Pecu. 2010. Vol. 23. Pp. 451-461.

16. Chowdhury J.U., Nandi N.C., Uddin M., Rahman M. Chemical constituents of essential oils from two types of spearmint (Mentha spicata L. and M. cardiaca L.) introduced in Bangladesh // Bangladesh J. Sci. Ind. Res. 2007. Vol. 42. N1. Pp. 79-82.

17. Soković M.D., Vukojević J., Marin P.D., Brkić D.D., Vajs V., van Griensven L.J.L.D. Chemical composition of essential oils of Thymus and Mentha species and their antifungal activities // Molecules. 2009. Vol. 14. Pp. 238-249.

18. Orav A., Kapp K., Raal A. Chemosystematic markers for the essential oils in leaves of Mentha species cultivated or growing naturally in Estonia // Proceedings of the Estonian Academy of Sci. 2013. Vol. 62. N3. Pp. 175-186.

19. Golparvar A.R., Hadipanah A., Gheisari M.M. Comparative analysis of chemical composition of three ecotypes of spearmint (Mentha spicata L.) in Isfahan province // Tech. J. Engin. App. Sci. 2013. Vol. 3. Pp. 1849-1851.

20. Stoeva T., Iliev L. Influence of some phenylurea cytokinins on spearmint essential oil composition // Bulg. J. Plant Physiol 1997. Vol. 23. N3-4. Pp. 66-71.

21. Gökbulut A., Şarer E. Simultaneous determination of phenolic compounds in Mentha spicata L. subsp. spicata by RPHPLC // Turk. J. Pharm. Sci. 2010. Vol. 7. N3. Pp. 249-254.

22. Tahira R., Naeemullah M., Akbar F., Masood M.S. Major phenolic acids of local and exotic mint germplasm grown in Islamabad // Pak. J. Bot. 2011. Vol. 43. Pp. 151-154.

23. Court W.A. HP reverse phase LC of naturally occurring phenolic compounds // J. Chromatogr. 1977. Vol. 130. Pp. $287-291$.

24. Murrough M.I., Hennigan G.P., Loughrey M.J. Quantitative analysis of hop flavonols using HPLC // J. Agric. Food Chem. 1982. Vol. 30. Pp. 1102-1106.

25. Методы технохимического контроля в виноделии / под ред. В.Г. Гержиковой. Симферополь, 2002. 259 с.

26. Плешков Б.П. Практикум по биохимии растений. М., 1985. 256 с.

27. Кривенцов В.И. Методические рекомендации по анализу плодов на биохимический состав. Ялта, 1982. $22 \mathrm{c.}$

28. Petersen M., Simmonds M.S.J. Rosmarinic acid // Phytochemistry. 2003. Vol. 62. Pp. 121-125.

29. Murakami K., Haneda M., Qiao S. Prooxidant action of rosmarinic acid: Transition metal-dependent generation of reactive oxygen species // Toxicology in Vitro. 2007. N21. Pp. 613-617.

30. Sanbongi C., Takanowz H., Osakabe N. Rosmarinic acid in perilla extract inhibits allergic inflammation induced by mite allergen, in a mouse model // Clin Exp Allergy. 2004. N34. Pp. 971-977.

Поступило в редакиию 22 мая 2014 г.

После переработки 29 августа 2014 г. 
Grebennikova O.A. , Palij A.E., Hristova Iu.P. BIOLOGICALLY ACTIVE SUBSTANCES OF MENTHA SPICATA L.

Nikita Botanical Garden, urban settlement Nikita, Yalta, Republic of Crimea, 298648 (Russia),

e-mail: oksanagrebennikova@yandex.ru

The data about qualitative and quantative composition of biologically active substances (volatile compounds, phenolic substances, vitamins) in water-ethanolic extract of promising specimen of Mentha spicata L. bred in NBS-NSC have been given in the paper. The concentration of volatile compounds in the spearmint water-ethanolic extract was $373,8 \mathrm{mg} / 100 \mathrm{~g}$. $46 \mathrm{com}$ ponents have been determined in the extract, 42 - have been identified. Carvone $(29,3 \%)$ and limonene $(9,7 \%)$ are the major and most valuable volatile compounds of spearmint extract. The content of phenolic substances in the water-ethanolic extract of spearmint was $2260,0 \mathrm{mg} / 100 \mathrm{~g} .17$ components have been determined in the extract. Among the phenolic substances of spearmint extract rosmarinic acid $(57,8 \%)$ dominates. The conclusion about possibility of use this extract to create food and health care products has been made.

Keywords: Mentha spicata L., water-ethanolic extract, gas chromatography-mass spectrometry, HPLC, volatile compounds, phenolic substances, vitamins.

\section{References}

1. Arumugam P., Ramamurthy P., Thyagarajan Santhiya S., Ramesh A. Asia Pac J Clin Nutr. 2006, vol. 15, no. 1, pp. 119-124.

2. Boukhebti H., Nadjib Chaker A., Belhadj H., Sahli F., Ramdhani M., Laouer H., Harzallah D. Der Pharm. Lett. 2011, vol. 3, no. 4, pp. 267-275.

3. Nickavar B., Alinaghi A., Kamalinejad M. Iran. J. of Pharm. Res. 2008, vol. 7, no. 3, pp. 203-209.

4. Fialová S., Tekel’ová D., Mrlianová M., Grančai D. Acta facultatis pharmaceuticae universitatis comenianae, 2008, vol. 55, pp. 96-102.

5. Hua C.X., Wang G.R., Lei Y. Afri. J. Biotechnol. 2011, vol. 10, pp. 16740-16745.

6. Naidu J.R., Ismail R.B., Yeng C., Sasidharan S., Kumar P. Phytology. 2012, vol. 4, no. 1, pp. 13-18.

7. Al-Tawaha A., Al-Karaki G., Massadeh A. Adv. Environ. Biol. 2013, vol. 7, no. 5, pp. 902-910.

8. Bensabah F., Lamiri A., Naja J. Int. J. Engin. Sci. and Technol. 2013, vol. 3, no. 1, pp. 44-48.

9. Kizil S., Naşimi N., Tolan V., Kilinç E., Yüksel U. Turk. J. of Field Crops. 2010, vol. 15, no. 2, pp. 148-153.

10. Shailendra Singh C., Ruchi A. J. of Drug Delivery Therapeutics. 2013, vol. 3, no. 4, pp. 120-121.

11. Martins M.R., Tinoco M.T., Almeida A.S., Cruz-Morais J. Pharmacognosy. 2012, vol. 3, no. 1, pp. 39-44.

12. Raturi P., Sharma A. Int. J. of Engin. and Mathem. Sci. 2012, vol. 1, no. 1, pp. 22-26.

13. Abd El- Wahab M.A. Res. J. Agric. Biol. Sci. 2009, vol. 5, no. 3, pp. 250-254.

14. Padalia R.C., Verma R.S., Chauhan A., Sundaresan V., Chanotiya C.S. Maejo Int. J. Sci. Technol. 2013, vol. 7, no. 1, pp. 83-93.

15. Roldan L.P., Diaz G.J., Duringer J.M. Rev Colomb Cienc Pecu. 2010, vol. 23, pp. 451-461.

16. Chowdhury J.U., Nandi N.C., Uddin M., Rahman M. Bangladesh J. Sci. Ind. Res. 2007, vol. 42, no. 1, pp. 79-82.

17. Soković M.D., Vukojević J., Marin P.D., Brkić D.D., Vajs V., van Griensven L.J.L.D. Molecules. 2009, vol. 14, pp. 238-249.

18. Orav A., Kapp K., Raal A. Proceedings of the Estonian Academy of Sci. 2013, vol. 62, no. 3, pp. 175-186.

19. Golparvar A.R., Hadipanah A., Gheisari M.M. Tech. J. Engin. App. Sci. 2013, vol. 3, pp. 1849-1851.

20. Stoeva T., Iliev L. Bulg. J. Plant Physiol. 1997, vol. 23, no. 3-4, pp. 66-71.

21. Gökbulut A., Şarer E. Turk. J. Pharm. Sci. 2010, vol. 7, no. 3, pp. 249-254.

22. Tahira R., Naeemullah M., Akbar F., Masood M.S. Pak. J. Bot. 2011, vol. 43, pp. 151-154.

23. Court W.A. J. Chromatogr. 1977, vol. 130, pp. 287-291.

24. Murrough M.I., Hennigan G.P., Loughrey M.J. J. Agric. Food Chem. 1982, vol. 30, pp. 1102-1106.

25. Metody tehnohimicheskogo kontrolja $v$ vinodelii. [Technochemical control methods in winemaking]. Ed. V.G. Gerzhikova. Simferopol', 2002, 259 p. (in Russ.).

26. Pleshkov B.P. Praktikum po biohimii rastenij. [Workshop on Plant Biochemistry]. Moscow, 1985, 256 p. (in Russ.).

27. Krivencov V.I. Metodicheskie rekomendacii po analizu plodov na biohimicheskij sostav. [Guidelines on the analysis on the biochemical composition of fruits]. Jalta, 1982, 22 p. (in Russ.).

28. Petersen M., Simmonds M.S.J. Phytochemistry. 2003, vol. 62, pp. 121-125.

29. Murakami K., Haneda M., Qiao S. Toxicology in Vitro. 2007, no. 21, pp. 613-617.

30. Sanbongi C., Takanowz H., Osakabe N. Clin Exp Allergy. 2004, no. 34, pp. 971-977. 